\title{
アブミ骨動脈遺残の一例
}

\author{
広野 喜信・山本 悦生
}

\section{A Case of Persistent Stapedial Artery}

\section{Yoshinobu Hirono and Etsuo Yamamoto \\ (Kyoto University)}

A 43-year-old female had bilateral otosclerosis with a persistent stapedial artery only in the left ear. This artery measured approximately $0.4 \mathrm{~mm}$ in diameter. It was seen on the floor of the tympanic cavity, ran between the crura of the stapes and entered the facial canal. At the time of left ear surgery we could perform stapedectomy after cutting this artery and stopping bleeding. A satisfactory hearing gain was obtained in both ears after stapedectomy.

Key words: stapedial artery, persistent, otosclerosis

\section{はじめに}

胎生期に存在するアブミ骨動脈が生後も遺残 する例は非常にまれで，主に側頭骨病理所見や 中耳手術中に発見されるが, 報告例は欧米で27 例 ${ }^{12}$ 20), 本邦では 2 例 ${ }^{2122)}$ のみである. われわ れはこのアブミ骨動脈が遺残した耳硬化症の一 例を経験したので，若干の文献的考察を加えて 報告する。

\section{症例}

患者 : 43歳, 女性

\section{主訴：左難聴}

家族歴：特記すべきととなし

既往歴 : 20歳頃, 左急性中耳炎

現病歴： 3 年前より左難聴, 左耳閉感, 高調 性耳鳴（左>右）が出現し，てれら耳症状は徐 々に増悪した。

検査所見：両鼓膜に著変なく, 聴力は図 1 の 如く両側之も中等度の混合性難聴を示した。テ ィンパノグラムは両側 $\mathrm{A}$ 型，耳小骨筋反射は両
側無反応であった。単純耳レ線，側頭骨の高分 解能 C T 像で異常所見を認めなかった。

手術所見：以上より中耳伝音障害を疑い，左 耳の試験的鼓室開放術を行った。耳内切開で鼓

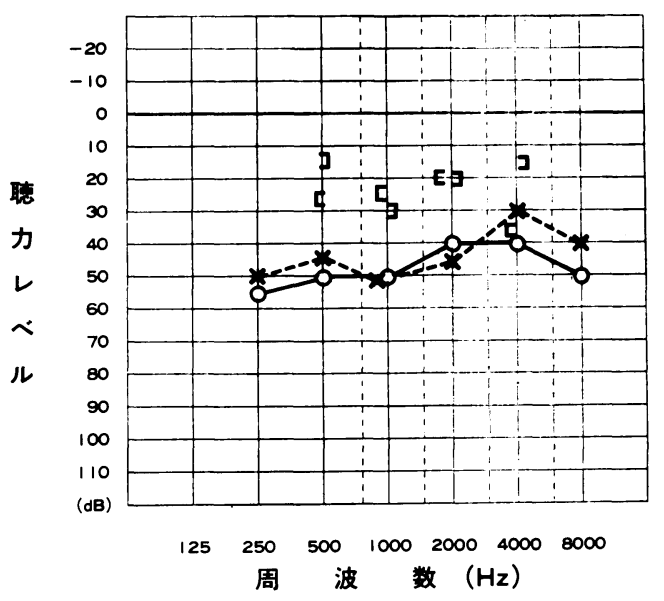

図 I 術前聴力検查所見 
室を開放すると，アブミ骨は底部で固着して不 動であり，耳硬化症と診断された。しかしッ チキヌタ，アブミの各耳小骨および関節部の

\section{A}
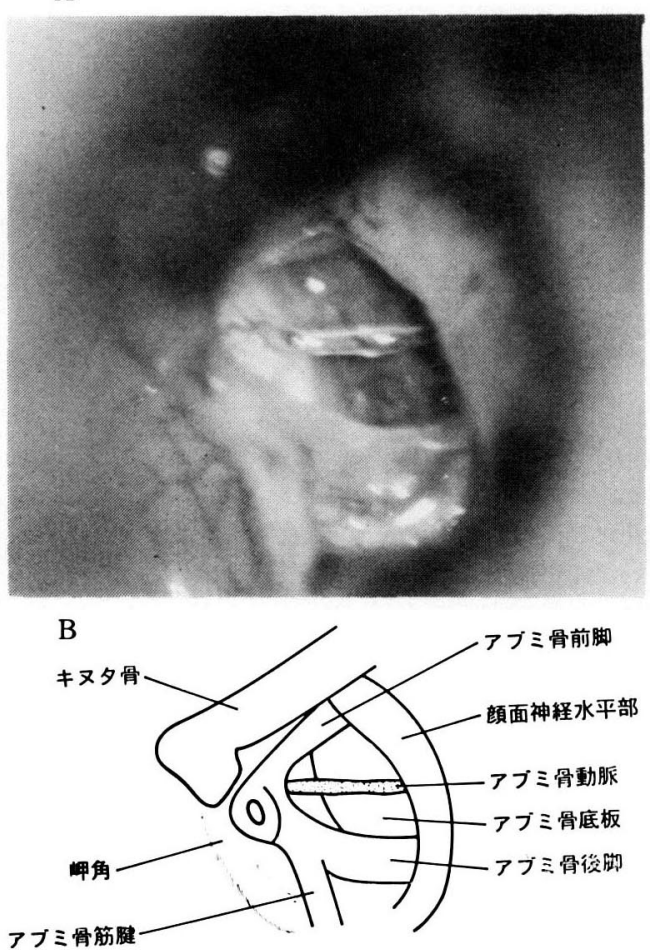

図2 A：手術所見（アブミ骨動脈） B：模式図

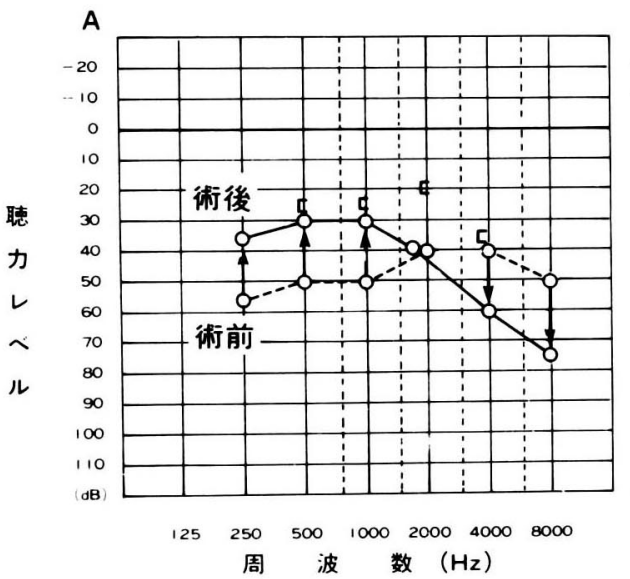

形態は正常であった。 また，鼓索神経の走行に 異常なく，顔面神経管の骨欠損や走行異常屯な かった。

特異な所見として，アブミ骨の前脚と後脚の 間を通って底板上を走る細血管（径約 $0.4 \mathrm{~mm}$ ) を認めた。この紐血管は拍動性で，鼓室下壁か ら岬角上を走行し，アブミ骨の前後脚間を通っ て，サジ状突起のすぐ後方で顔面神経管内に入 っており，その特異な上行からアブミ骨動脈の 遗残と考えられた（図 2 )。手術操作を進める ために，この細晌管をアブミ骨底板より外側の 雨端で切断した所，かなりの出血を認めたが,

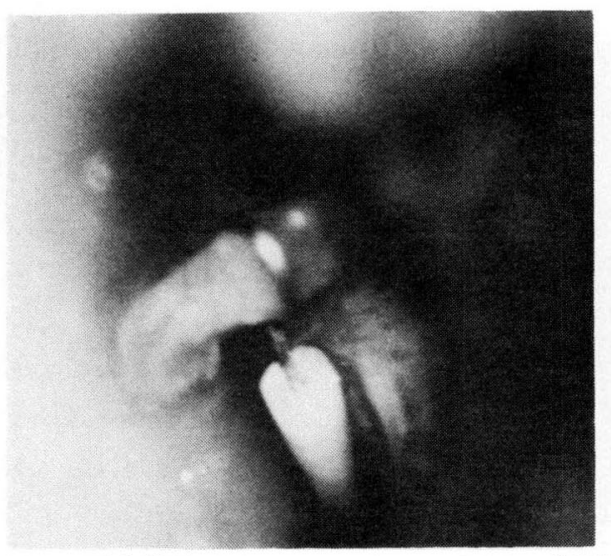

図 3 手術所見（テフロンワイアーピストン留置）

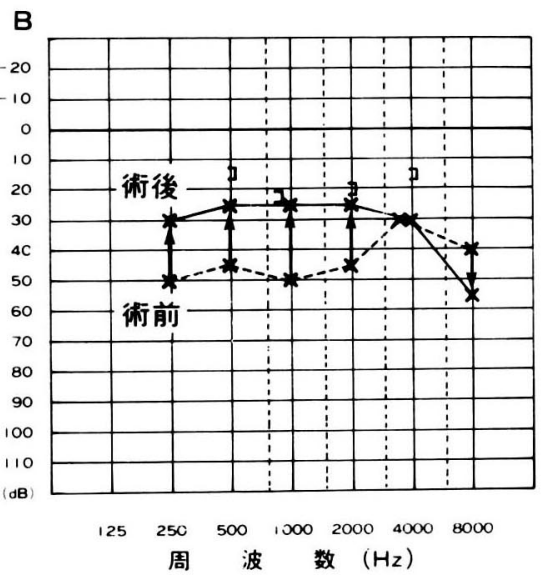

図 $4 \mathrm{~A}$ ：右耳聴力経過（術後 6 力月）

B : 左耳聴力経過（術後 1 年） 
耳小骨麦粒鈷子の圧迫で止血できた．型のごと くアブミ骨を全摘出し，シュークネヒト型テフ ロンワイアーピストン（外径 $0.6 \mathrm{~mm}$, 長さ $4 \mathrm{~mm}$ ) を用い（図 3 )，ピストン部と卵円空との間に 側頭筋肉片を置いた。約 6 力月後に右耳屯鼓室 開放術を行い, 耳硬化症を確認してアブミ骨摘 出術を施行したが，右耳ではアブミ骨動脈の遺 残は認められなかった。聴力は両側とも著明に 改善した（図 4 )。現在, 術後左耳 1 年半, 右 耳 1 年であるが聴力は不変である.

\section{考案}

アブミ骨動脈は舌省動脈の分枝で胎生 4 ない し 5 週に出現し，アブミ骨原基の中心を走行す る ${ }^{23)}$. これがアブミ骨閉鎖孔形成の原因とされ ている ${ }^{8}$. アブミ骨動脈の発育の極期（胎生 6.5週）には，三叉神経の分枝に対応する眼窝 上枝，眼窩下枝，下顎枝を有している（図 5 ). その後, 顎動脈之なる外頸動脈からの吻合枝が 出現すると, アブミ骨動脈は萎縮し, 胎生 3 力 月中には消失する $(\text { 図 } 6)^{6}$.

Altmann ${ }^{6}$ によれば，アブミ骨動脈が生後 も遺残すると, 直径約 $2 \mathrm{~mm}$ で, 鼓室下壁に出現 し, 岬角を後上方に走行し, アブミ骨の前, 後 脚の間を通り，さじ状突起のすぐ後方で顔面神 経管に入り膝神経節の $2 \mathrm{~mm}$ 後方で離れ, 脳硬膜 と中頭蓋窩内面の間を上方に走行するという.

本症例の血管はその特異な走行の点では遺残 アブミ骨動脈に一致するが, 直径が $0.4 \mathrm{~mm}$ 之細 い. アブミ骨領域のいかなる血管も，胎生期の アブミ骨動脈として同定できないといわれてい

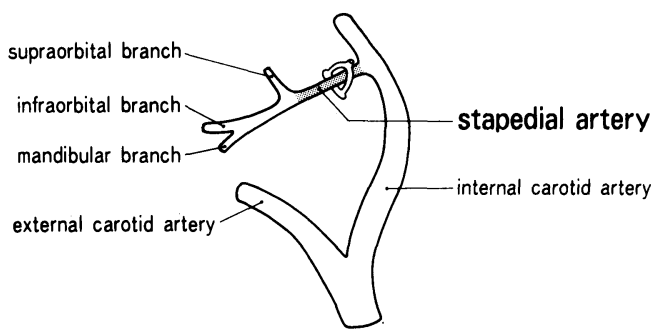

図 5 胎生6.5週のアブミ骨動脈 (Altmann（1947）を改変)
るが24), 径0. $25 \mathrm{~mm}$ 以下でも走行が一致すればア ブミ骨動脈の遺残とされている(7)15)20). 本症例 屯顔面神経周囲の動脈叢に終るアブミ骨動脈の 不完全遺残例 ${ }^{20)}$ と考えられた。

本血管は頭頸部や中耳の奇形，顔面神経の走 行異常に伴うことが多いとされ, 耳硬化症を合 併した例は文献的にみると本例を含めて30例中 5 例10)1122)である.

アブミ骨手術中に本血管に遭遇すると，その 処理をせまられる．従来の報告ではいずれも血 管を避け，底板の一部のみを除去し wire prosthesis 使用している. 本症例では幸い血 管が細かったのでてれを切断して，底板の全摘 出ができた。しかし，本血管の完全遺残例では 中硬膜動脈を分枝し ${ }^{6)}$, 血管傷害で大量出血を 来し ${ }^{12)}$ ，また本血管の結禁で一過性の片麻瘏を 来しうるとされている ${ }^{25)}$. 内頸動脈血管造影で

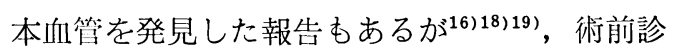
断は難しい. 本血管遺残の頻度は House ${ }^{11)}$ に よると8000例中 2 例之非常にまれであるが，他 種奇型を伴う例や耳硬化症では本血管を念頭に 抢いて手術をする必要があろう。

本血管の遺残は，拍動性耳鳴の原因になると 推測されているが8), 報告例は 1 例のみであ る ${ }^{16)}$. しかし，本症例でみられた耳鳴は高調性 であり，かつ両耳とも耳鳴の性状は同じである 所から，本血管に起因する耳鳴でないと考えら れた.

\section{まとめ}

アブミ骨前脚と後脚間を通る㨁径 $0.4 \mathrm{~mm}$ のア

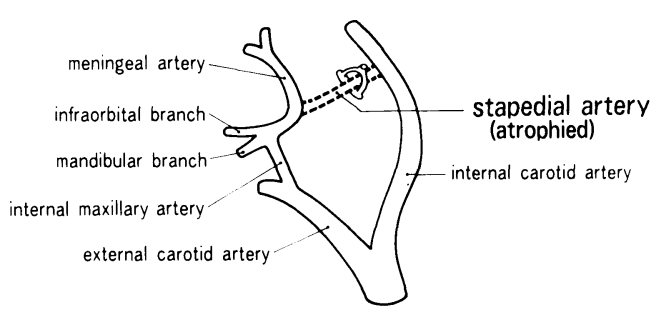

図 6 胎生 3 カ月のアブミ骨動脈 (Altmann (1947) を改変) 
ブミ骨動脈が左耳だけに遺残した両側耳硬化症 の 1 例を報告した。両耳ともアブミ骨摘出術 （左耳では本血管を切断，止血した上で）を行 い, 恥力の改善を得た。

本庄 簏教授の御校閲を深謝致します. なお本論文の要旨は第13回臨床耳科学会で発表し た.

\section{参考文献}

1) Hyrtl $\mathrm{J}:$ Neue Beobachtungen aus dem Gebiete der menschlichen und vergleichenden Anatomie : 3. Uber mehrere im Menschen vorkommende Analogieen Derjeningen Arterie welche Otto bei mehreren Winterschlafern durch den Steigbügel verlaufend entdeckte. Med Jahrb Oesterreich Staates $10: 457 \sim 466,1836$.

2) Zuckerkandle E : Uber die A. Stapedia des Menschen. Monatsschr Ohrenheilk $7: 6 \sim$ $7,1873$.

3) Alexander G : Ein Fall von Persistenz der Arteria Stapedia beim Menschen. Monatsschr Ohrenheilk 33:273 276, 1899.

4) Lewin L: Das Vorkommen von Persistenz der A. Stapedia beim Menschen und die Vergleichend anatomiche und entwicklungsgeschichtliche Bedeutung Dieses Phano mens. Arch Ohrenheilk $70: 28 \sim 44,1906$.

$5)$ Brock W : Drei Neue Falle von Persitierender Arteria stapedia beim Menschen. Monatsschr Ohrenheilk $56: 683 \sim 685,1922$.

6) Altmann F : Anomalies of the internal carotid artery and its branches; their embryological and comparative anatomical significance. Report of a new case of persistent stapedial artery in man. Laryngoscope $57: 313 \sim 339,1947$.

7) Altmann $F:$ The ear in severe malformations of the head. Arch Otolaryngol 66 : $7 \sim 25,1957$.

8) Kelemen G: Arteria stapedia in bilateral persistence. Arch Otolaryngol $67: 668 \sim$ 677, 1958.
9) Fowler EP:Variations in the temporal bone course of the facial nerve. Laryngoscope $71:$ 937 946, 1961.

10) Baron SH : Persistent stapedial artery, necrosis of the incus and other problems which have influenced the choice of technique in stapes replacement surgery in otosclerosis. Laryngoscope $73: 769 \sim 782$, 1963.

11) House HP, et al : Persistent stapedial artery : Report of two cases. Trans Am Acad Ophthalmol Otolaryngol $68: 644 \sim 646$, 1964.

12) de Pinies F, et al : Persistence of stapedial artery. Arch Otolaryngol $80: 134 \sim$ 135, 1964.

13) Maran AGD : Persistent stapedial artery. J Laryngol Otol 79: 971 975, 1965.

14) Davis DG: Persistent stapedial artery. A temporal bone report. J Laryngol Otol 81 : 649 660, 1967.

15) Sando I, et al : Persistence of stapedial artery in trisomy 13-15 syndrome. Arch Otolaryngol $96: 441 \sim 447,1972$.

16) Guinto FC, et al : Radiology of the persistent stapedial artery. Radiology $105: 365$ $\sim 369,1972$.

17) Hoogland GA, et al : The facial nerve coursing across the promontry with a persistent stapedial artery. ORL $39: 338 \sim 341$, 1977.

18) Dilenge D, et al : Variations of the ophthalmic and middle meningeal arteries: Relation to the embryonic stapedial artery. AJNR । : 45 53, 1980.

19) Castroviejo IP : Persistence of the stapedial artery in a first arch anomaly: A case report. Cleft Palate Journal $20: 146 \sim 150$, 1983.

20) Marion $M$, et al : Persistence of the stapedial artery: A histopathologic study. Otolaryngology Head and Neck Surgery 93 : 298 312, 1985. 
21) Adachi B : Das Arteriensystem der Japaner. Acta Sch Med Univ Kyoto 9 (suppl 1) : 99 $\sim 102,1927$.

22）增田 游, 他: Persistent stapedial artery t 伴った耳硬化症の 1 例. 臨床耳科 II：294〜295, 1984.

23) Padget DH : The development of the cranial arteries in the human embryo. Contrib Embryol $32: 205 \sim 261,1948$.

24) Nager GT, et al: The arteries of the human middle ear with particular regard to the blood supply of the auditory ossicles. Ann Otol Rhinol Laryngol $62: 923 \sim$ 949, 1953.

25) Hogg ID, et al : Theoretical anomalies of the stapedial artery. Ann Otol 81:860 $870,1972$.

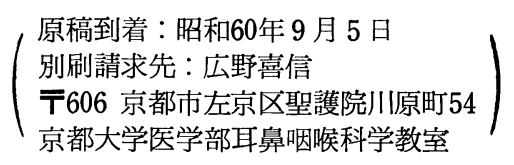

